\title{
Interesting breeding cases of the Raven (Corvus corax) in Hungary
}

\author{
János BagYuRA ${ }^{1 *}$, József FidlócZKY ${ }^{1}$, Vince SchWARTZ \\ \& László TóTH ${ }^{2}$
}

Received: January 16, 2017 - Accepted: February 23, 2017

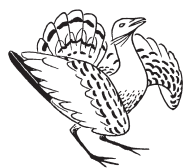

Bagyura, J., Fidlóczky, J., Schwartz, V. \& Tóth, L. 2017. Interesting breeding cases of the Raven (Corvus corax) in Hungary. - Ornis Hungarica 25(1): 39-43. DOI: 10.1515/orhu-2017-0003 ving large flocks is not rare. Compared to other European countries, the urbanization of the species began relatively late in Hungary, in the ' $90 \mathrm{~s}$, first breeding in the urban areas of Baranya County. There were another five similar known cases after the millennium across the country. Because of the advanced adaptive capacity of species, this number is likely to grow in the future.

In Hungary, the brood is typically complete in the second half of February and the young birds fledge in the first days of May. There are two known cases after the millennium when the Ravens bred in a significantly different time than usual. In these cases, the young birds fledged on 20 January and the second half of February. In both cases, the nests were found on overhead transmission line poles in lowland agricultural areas. It is uncertain what led to the unusual breeding time, but it is most likely that the breeding pair was accustomed, having successfully raised several brood before, and they could rely on the abundant food base near the nests during the breeding period.

Keywords: Raven, early breeding, urbanization

Összefoglalás Magyarországon a holló költőállománya az utóbbi évtizedekben - a természetvédelmi intézkedéseknek köszönhetően - jelentősen megerösödött, és a faj síkvidéken is megjelent, mint fészkelő. Manapság a nagyobb csapatok megfigyelése sem ritka. Más európai országokhoz képest Magyarországon viszonylag későn, a '90-es években kezdődött el urbanizálódása, elsőként Baranya-megyében költött belterületen. Az ezredfordulót követően országszerte további öt hasonló esetről tudunk. A faj fejlett adaptációs képessége miatt ez a szám a jövőben vélhetően növekedni fog.

Magyarországon a párok fészekalja általában február második felében már teljes, és a fiatalok május első napjaiban repülnek ki. Az ezredfordulót követőn két olyan esetet ismerünk, amikor a hollók a megszokottól jelentősen eltérő időpontban költöttek. Ezeknél a költéseknél a fiatalok január 20-án, illetve február második felében repültek ki. A fészkek mindkét esetben síkvidéki mezőgazdasági területen, távvezeték-tartóoszlopon voltak. Nem lehet pontosan megállapítani, hogy a szokatlan időpontban történő költésekhez konkrétan milyen okok vezettek, de valószínủ, hogy a madarak egyrészt már több fészekaljat sikeresen felnevelő, összeszokott költőpárok voltak, másrészt bőséges táplálékbázisra támaszkodhattak a fészkek közelében a költések ideje alatt.

Kulcsszavak: holló, korai költés, urbanizáció

\footnotetext{
${ }^{1}$ BirdLife Hungary, 1121 Budapest, Költö utca 21., Hungary

${ }^{2}$ Bükk National Park Directorate, 3304 Eger, Sánc utca 6., Hungary

*corresponding author
} 


\section{Introduction}

The distribution of the Raven almost completely covers the North American and Eurasian part of the Holarctic zoo-geographical region from the Arctic areas to temperate habitats; in addition, it also nests in the Mediterranean and desert areas of northern Africa and Oceania (Benson 1972).

According to the database of the Integrated Taxonomic Information System (http://www. itis.gov/), currently eleven approved subspecies occur in the total distribution area of the species, from which five subspecies nest regularly in Europe. The ssp. hispanus (Hartert \& Kleinschmidt 1901) nests in some parts of the Iberian Peninsula, the Balearic Islands, Corsica and Sardinia, and the Apennine Peninsula.

The distribution area of the ssp. laurencei (Hume 1873) stretches from the Eastern Mediterranean to China. In Europe, it nests in the eastern parts of Greece and in Cyprus. The ssp. canariensis subspecies with smaller distribution (Hartert \& Kleinschmidt 1901) nests only in the Canary Islands, while the ssp. varius (Brünnich 1764) in the Faeroe Islands and Iceland. The core ssp. corax (Linnaeus 1758) has the largest distribution area, nesting from the British Isles to the West Siberian Jenyiszei River, including most part of the European continent (Ratcliffe 1997).

In Hungary, only the core ssp. corax occurs, which nests regularly and is a stable member of the Hungarian avifauna. Until the mid-1970s, it was nesting mainly in the mountain region. Its population size at that time was estimated at 30 pairs (Magyar et al. 1998). In the last decades, due to conservation measures - mainly the elimination of poisoning - there was a significant increase in the number of nesting pairs and also a significant increase in their distribution area, as the species moved down towards the Great Plains (Haraszthy 1998a). Today a nationally distributed species, the population size was estimated to be 2000-3100 pairs over the period of 1999-2002 (Hadarics \& Zalai 2008). The Hungarian breeding population of the Raven is certainly still rising, which - in the absence of species-specific monitoring - can be inferred primarily from the data of local observers. The more common observation of large flocks can be attributed to this growth.

For example, in the landfill site and pig farm bordering Dunakeszi, as well as the Bear Park area in Veresegyháza, due to favourable feeding opportunities, flocks of 120-150 birds can be observed. There are similar observations also from other parts of the country, such as the landfill sites at the border of Gödöllö and Bodrogkeresztúr or the now rehabilitated, former garbage dump at the border of Márianosztra, where a flock of more than a hundred birds was observed (Schwartz ex verb.). In April 2016, a flock of over 200 birds resided near the border of Pócsmegyer that came to feed on the low land (Schwartz ex verb.).

\section{Urbanization}

With regard to urbanization of the Raven, the earliest data for Europe originates from the United Kingdom. One pair settled in the Tower of London sometime in the medieval period (Ratcliffe 1997). 
In the $20^{\text {th }}$ century, nesting and colonization was observed in more and more European settlements, mainly in major cities, such as the urban areas of Moscow, London, Bern and Lviv (Konstantinov et al. 1996, Ratcliffe 1997).

In the Central and Eastern European region, it first appeared in Poland in the '50s, nesting in the outskirts of cities and around urban parks (Zawadzka \& Zawadzki 2014).

In Hungary, the urbanization of the Raven started some decades ago in Baranya County. It first nested on pine trees in the inner area of Szentegát in 1991, and between 2000-2007, nests were found on a water tower and grain dryer in the urban areas of Felsőszentmárton. In 2011, it also nested successfully on pine trees in the urban areas of Bóly. The territories in Szentegát and Bóly are still in use (Bank ex verb.).

In 2012, it settled and nested successfully in an abandoned, but for recreational purposes constantly disturbed, limestone quarry wall in the residential area of the $3^{\text {rd }}$ district of Budapest, where it has still bred every year since (Lendvai ex verb.).

In 2013, one pair settled on the Basilica building in Komárom-Esztergom County and successfully bred twice (Schwartz ex verb.).

In Pest County in 2015, one pair settled in the busiest area of Gödöllő Castle Park and bred successfully on a pine tree (Schwartz ex verb.).

Ravens, due to their developed ability of adaptation, can tolerate well the effects of permanent human presence, and therefore in the residential areas, the number of nesting pairs is likely to increase in the future.

\section{Early breeding}

In Europe, the Raven breeds at approximately two-month intervals. The start of the egg laying period falls between the end of February and end of April.

In the UK and Ireland, they lay their first eggs from 19 February to 8 March (Holyoak 1967, Allin 1968, Elliott \& Nuttall 1983, Dare 1986, Davis \& Davis 1986), in the first half of March in France (Géroudet 1980), and between 15 March and 31 April on the Iberian Peninsula (Lopez del Pozo ex verb.).

On rare occasions, the breeding period can deviate from the usual, e.g. shift to autumn. On the first day of Christmas in 1822, in a forest near Sülyi, Szatmár County (now called Szamossályi, part of Ukraine), three fully fledged Raven chicks were retrieved from the top of a tree. The young birds were forecast to leave the nest in a weeks' time according to an observer. According to the data published by an unknown author, the birds might have started breeding earlier as usual because of the unusually long and warm autumn (Anonim 1823).

On 13 October 1945, on the Howgill cliff near Sedbergh, England, a whole brood was found after a failed incubation period (Ratcliffe 1997).

On 3 April 1969, on the sandstone cliff in Gürbetal near Thun, Switzerland, young Ravens were observed that left a nest that had been known for a long time. Based on the observations, they could have flown out between 1-2 April. The nest was found at the altitude of 820 meters above sea level (Hauri 1970).

In November 1988, a brood of 6 chicks was found in South-Wales (Mearns \& Mearns 1989). 
In 1 January 1989, a flying chick was found in the coastal zone of Galloway, Scotland (Ratcliffe 1997).

In 2000, two chicks fledged from a nest found on an overhead transmission line pole between Čel'ovce and Úpor (Trebišovi area), Slovakia (Balla et al. 2001).

In Hungary, the Ravens belong to the earliest breeding birds. The accustomed couples' brood is usually complete in the second half of February, and the young fledge on the first days of May. Unusual timing in breeding also occurred here. In 2005, on the Moson Plain (Györ-Moson-Sopron County), a Raven pair occupied an artificial nest placed out for the Saker Falcon (Falco cherrug) on an overhead transmission line pole, and bred successfully in the usual early spring period. In the same year on 9 December, a female was incubating eggs, and on 16 December, a Raven feeding its chick was observed. On 20 January 2006, three successful chicks were documented and one juvenile was found dead under the pole (Váczi 2007).

On 17 January 2015 in the Besenyőtelek area (Heves County) in Hungary, during the $12^{\text {th }}$ national annual counting of birds of prey, János Bagyura, József Fidlóczky, Flóra Hák and Gabriella Leskó observed 3 chicks that were close to fledging in a nest located on an overhead transmission line pole. The birds eventually fledged between 19-22 February. In parallel to the fledging, the couple performed a mating dance but did not start breeding again. In 2016, the same pair started breeding at the usual time in February on the same breeding spot. This Raven territory is known for nearly eight years.

Examining the circumstances of the above cases, it cannot be determined exactly what led to the unusual time of the breeding, there are only assumptions.

A parallel can be drawn between the $21^{\text {st }}$ century Carpathian data with respect to the nesting sites, because in all four cases, the nesting happened on overhead transmission line poles in lowland agricultural areas. The general opinion is that for the Raven, the initial date of egg-laying and the absolute height of the nesting place have a strong correlation, just as it was evinced in the case of the Common Buzzard (Buteo buteo) in Hungary (Haraszthy 1998b). In Northern England, 50 meter increase in altitude showed an average of one day delay in the start date of egg-laying (Ratcliffe 1997). In Northern Wales at higher altitudes (300 $\mathrm{m}$ above sea level), in $81.3 \%$ of the cases, the breeding started later than usual (Allin 1968). The core ssp. corax can be found in the United Kingdom where humid maritime climate is prevailing, while in the Carpathian Basin, there are also maritime, continental and Mediterranean effects.

It is likely that the published Hungarian cases apply to accustomed breeding pairs that have successfully reared several broods during their lifetime. In these years, plenty of food was available. In the 2005 and 2015 cases, there was a gradation in the vole population in the region. Considering the Raven's generalist feeding habits (Heinrich et al. 1995), the abundance of internal organ remains near the nest after intensive hunts, or the close proximity of a waste dump, can also facilitate early breeding.

The expansion of the Raven on lowlands and its urbanization clearly shows that the breeding population, after an earlier crash, is now on a growing path. This is mainly the result of general conservation measures (i.e. prohibiting the use of pesticides and the ban on game control with the use of poison), which contributed to breeding success and survival of young birds during the dispersion period. 


\section{Acknowledgements}

We are grateful for all who provides data for this review, for the constructive comments from Tibor Csörgö on the previous version of the manuscript and for József Vuts for his English proof correction.

\section{References}

Allin, E. K. 1968. Breeding notes on Ravens in north Wales. - British Birds 61: 541-545.

Anonim 1823. Természeti ritkaságok [Rarities in nature]. - Hasznos Mulatságok [Useful amusements]. - 1823 Első félesztendő (7): 55-56. (in Hungarian)

Balla, M., Mihók, J. \& Danko, Š. 2001. Hniezdenie krkavca (Corvus corax) v jesennon a zimnom období [Breeding of Common Raven (Corvus corax) in autumn and winter season]. - Tichodroma 14: 58-60. (in Slovakian with English Summary)

Benson, S. V. 1972. Raven Corvus corax. - In: Benson, S. V. (ed.) The Observer's Book of Birds. - Frederick Warne \& Co. Ltd., London, p. 140.

Dare, P. J. 1986. Raven Corvus corax populations in two upland regions of north Wales. - Bird Study 33: 179189. DOI: $10.1080 / 00063658609476918$

Davis, P. E. \& Davis, J. E. 1986. The breeding biology of a Raven population in central Wales. - Nature in Wales 3: 44-54.

Elliot, G. \& J. Nutall, J. 1983. A survey of Ravens in the Isle of Man. - Peregrine 5: 238-239.

Géroudet, P. 1980. Les Passereaux. I: du Coucou aux Corvidés [The Passerines. I: from the Cuckoo to the Corvidae]. - Neuchâtel - Paris (in French)

Hadarics, T. \& Zalai, T. (szerk.) 2008. Magyarország madarainak névjegyzéke. Nomenclator avium Hungariae [An annotated checklist of the birds of Hungary]. - Magyar Madártani és Természetvédelmi Egyesület, Budapest, p. 213. (in Hungarian and English)

Haraszthy, L. 1998a Holló Corvus corax [Common Raven Corvus corax]. - In: Haraszthy, L. (ed.) Magyarország madarai [Birds of Hungary]. - Mezőgazda Kiadó, Budapest, pp. 358-359. (in Hungarian)

Haraszthy, L. 1998b Egerészölyv Buteo buteo [Common Buzzard Buteo buteo]. - In: Haraszthy, L. (ed.) Magyarország madarai [Birds of Hungary]. - Mezőgazda Kiadó, Budapest, pp. 53-54. (in Hungarian)

Hauri, R. 1970. Aussergewöhnlich frühe Brut des Kolkraben [Exceptionally early breed of the Ravens]. - Ornithologische Beobachter 67: 63 (in German)

Heinrich, B., Marzluff, J. \& Adams, W. 1995. Fear and food recognition in naive Common Ravens. - The Auk 112(2): 499-503. DOI: $10.2307 / 4088740$

Holyoak, D. 1967. Breeding biology of the Corvidae. - Bird Study 14: 153-168. DOI: 10.1080/00063656709476159

Konstantinov, V. M., Nowicki, W. \& Pichurin, A. G. 1996. Recent changes in the avifauna of cities in European Russia and Eastern Poland - results of questionnaire. - Acta Ornithologica 31: 59-66.

Magyar, G., Hadarics, T. \& Waliczky Z. 1998. Nomenclator avium Hungariae. Magyarország madarainak névjegyzéke [An annotated checklist of the birds of Hungary]. - Madártani Intézet - MME - Winter Fair, Budapest - Szeged, p. 123 (in Hungarian)

Mearns, R. \& Mearns, B. 1989. Successful autumn nesting of Raven. - Scottish Birds 15: 179.

Ratcliffe, D. 1997. Breeding: the egg state. - In: Ratcliffe, D. (ed.) The Raven: A Natural History in Britain and Ireland. - T \& AD Poyser, London

Váczi, M. 2007. Érdekes adatok ritka madárfajokról a Kisalföldön [Interesting records of rare birds in the Small Hungarian Plain]. - Heliaca 2005: 114-115. (in Hungarian)

Zawadzka, D. \& Zawadzki, G. 2014. Synanthropisation and synurbisation of Raven Corvus Corax in Poland: A Review. - International Studies on Sparrows 38(1): 11-16. DOI: 10.1515/isspar-2015-0025 